\title{
From Moscow to Madrid: Postmodern Cities, European Cinema
}

\author{
By Dorota Ostrowska
}

\section{Fall 2004 Issue of KINEMA}

Mazierska's and Rascaroli's From Moscow to Madrid is a fascinating experiment in imaginary cartography, which explores the representation of cities in contemporary European cinema while drawing freely on film history, sociology, politics and cultural studies. The authors choose the postmodern discourse as a theoretical framework to analyze the complex psyche of modern European cities as it is filtered through the cinematic medium. Their cities are postmodern spectacles testifying to the death of God, to the collapse of any overarching and unifying myths and ideologies and to the ensuing fragmentation and diversification. Although the authors are fascinated by the scale of social, economic and political changes which orchestrated the shift from modern to postmodern city, they do not celebrate it but rather count the losses in sensibilities and examine the cracks in ideologies. What strikes in their account is sadness and nostalgia for some lost city which no longer has place in cinema because it no longer exists in reality. Strangely enough, in the closing sentence of the book the authors even seem to take some responsibility for this state of affairs when they write rather poignantly that "the barbarians are already here. ${ }^{(1)}$ (...)

Cohesion and centrality belong to the past, and we are now left to learn how to marginalize ourselves" (p. 240). This view points out to migration within Europe as one of the reasons for the fragmentation and disintegration of some cohesive model of European city, utopia, which existed in some not such distant past. But then Mazierska and Rascaroli are also capable of challenging their own pessimism and smiling through tears. In their discussion of Almodóvar's Madrid, of Machulski's Warsaw and Michell's London they acknowledge that something playfully ironic and humorous can exist in the midst of the postmodern chaos; that disintegration of the old releases energy which might perpetuate this world towards something new; finally, that not all change is traumatic, painful and destructive.

If the mix of pain and pleasure is one axis of this book, expressed through the interplay of postmodern ethics and aesthetics, politics is the other reflected in the structure of the book divided into three parts. Part One entitled "Old Europe" focuses on the cinematic rendition of Southern European cities of Naples, Madrid and Marseilles. The Second Part, "Postcommunist Europe," concerns itself with the representation of such cities as Berlin, Warsaw and Moscow.

Part Three is a case study of three British cities: London, Edinburgh and Blackpool. With this taxonomy Mazierska and Rascaroli propose a new imaginary map of Europe for our post-Thatcherite, postcommunist, post-Franco, post-Fordist and ultimately postmodern times. The authors are radical in that their Old Europe excludes what could be considered the continent's twin-heart, Paris and Rome, and instead they point out to the cities of the Mediterranean basins such as Naples and Marseilles which could be read as a gesture towards valuing regional over national identities. Madrid is presented as a city returning where it belongs, Old Europe, from the darkness of Franco's night.

The book is unique in giving so much careful attention to the cities of post-communist Europe. While Warsaw and Moscow are unquestionable examples of postcommunist cities, the authors also decide to count Berlin among them which highlights the fractured identity and debatable status of postcommunist Europe in relation to its Western capitalist counterparts. The authors also try to reclaim London for Europe because it is "thanks to London, Great Britain belongs, more than any other country in Europe, to a globalized, late capitalist economy" (p. 8). But British cities in this book seem to have a rather ambiguous and curious status as case studies which raises a question as to the reasons why they receive such special treatment. Given that the American metropolis characterized as postmodern is the main reference point for this book, it might be that British cities are particular examples of such a metropolis, which paradoxically takes them away from the Old World towards the new one.

Ethics and politics aside, From Moscow to Madrid is first and foremost a book about cinema. The authors point out that, more often than not, efforts to regenerate a city are accompanied by intensification of creative activity of which cinema is a particular example because of its power to offer a visual representation of the city - which could mirror the changes taking place there or present an alternative version of the transformation. 
From Moscow to Madrid is thus a travelogue through both familiar and unfamiliar real and imaginary cinematic cities and a useful introduction to lesser known regional cinemas and film-makers. Ultimately, the book is important because it demonstrates the power of cinema to take us beyond "the edges of the map" into the realm of imagination and fantasy which can be a place for renewal and symbolic regeneration of the whole European continent (p.2).

1. Note: Indeed some of us have now become the barbarians, namely the travellers and peoples from Eastern Europe and Southern Europe; Mazierska is originally Polish and Rascaroli Italian.

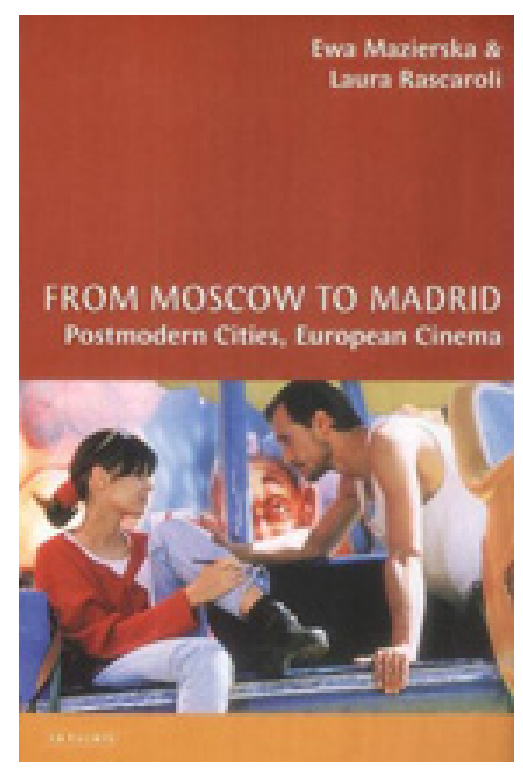

Figure 1: FROM MOSCOW TO MADRID: POSTMODERN CITIES, ๆ EUROPEAN CINEMA ๆ By: Ewa Mazierska and Laura Rascaroli 9 London and New York: I. B. Tauris, 2003 ๆ 260pp. I ISBN 1860648509 (hbk); 1860648517 (pbk)

\section{Notes}

1. Indeed some of us have now become the barbarians, namely the travellers and peoples from Eastern Europe and Southern Europe; Mazierska is originally Polish and Rascaroli Italian.

\section{Author Information}

Dorota OSTROWSKA is a lecturer in film studies at Edinburgh University in Scotland, UK. Her research interests are in French film theory, media convergence, European film industry and Eastern European cinema. She is currently preparing a book with Graham Roberts, European Cinemas in the TV Age for Edinburgh University Press. 